\title{
KAJIAN PENGUKURAN SKALA PENGALAMAN KERAWANAN PANGAN PADA RUMAH TANGGA PERTANIAN: HASIL UJI COBA SURVEI PERTANIAN TERINTEGRASI
}

\author{
Kadir $^{1}$, Octavia Rizky Prasetyo ${ }^{2}$ \\ ${ }^{1,2}$ Badan Pusat Statistik \\ ${ }^{1}$ kadirsst@bps.go.id ; ${ }^{2}$ octaviarizkyp@bps.go.id
}

Diterima: Februari 2021; Disetujui: Mei 2021

\begin{abstract}
Food Insecurity Experience Scale (FIES) measurement focusing on agricultural households has not been reported in Indonesia. This study aims to exercise FIES measurement to estimate the prevalence of food insecurity on agricultural households through the pilot of Integrated Agricultural Survey (SITASI) carried out in three provinces, namely West Java, East Java, and West Nusa Tenggara in 2020. The survey observed 1,300 households samples. FIES measurement applied on the survey to estimate the prevalence of food insecurity. Estimation was conducted by making use of the survey weight obtained from a multi-stage random sampling design. The results show that the FIES measurement can be applied to agricultural households through SITASI. All of assumptions underlying the validity of FIES measurement were met. In total, the prevalence rate of moderate or severe food insecurity in the three provinces is only $1.12 \%$ of total agricultural households. Meanwhile, the prevalence of severe food insecurity is only $0.12 \%$. These findings confirm that the incidence of food insecurity is quite rare in agricultural households. However, in absolute terms, the numbers are quite significant so it needs interventions, among others assistance to improve productivity, scaling-up agricultural cultivation, and social safety nets focusing on the access to food.
\end{abstract}

Keyword: agriculture, fies, food insecurity, sitasi.

Abstraksi. Pengukuran skala pengalaman kerawanan pangan (FIES) yang dikhususkan pada populasi rumah tangga pertanian belum pernah dilaporkan di Indonesia. Penelitian ini bertujuan mengkaji pengukuran FIES untuk mengestimasi prevalensi kejadian kerawanan pangan pada rumah tangga pertanian melalui uji coba Survei Pertanian Terintegrasi (SITASI) di tiga provinsi, yaitu Jawa Barat, Jawa Timur, dan Nusa Tenggara Barat pada 2020. SITASI mengobservasi 1,300 sampel rumah tangga di tiga provinsi tersebut. Pengukuran FIES diterapkan pada pelaksanaan survei untuk mengestimasi prevalensi kerawanan pangan, baik secara persentase maupun jumlah absolut. Estimasi dilakukan dengan menggunakan penimbang survei yang diperoleh dari rancangan penarikan sampel acak bertingkat. Hasil penelitian menunjukkan bahwa pengukuran FIES dapat diterapkan pada rumah tangga pertanian melalui SITASI. Semua asumsi yang mendasari validitas pengukuran FIES terpenuhi. Secara total, tingkat prevalensi kerawanan pangan moderat hingga parah di tiga provinsi lokasi uji coba hanya sebesar 1,12\% dari total rumah tangga pertanian. Sementara itu, prevalensi kerawanan pangan parah hanya sebesar 0,12\%. Temuan ini mengkonfirmasi bahwa kejadian kerawanan pangan cukup jarang terjadi pada rumah tangga pertanian. Meskipun begitu, secara absolut jumlahnya masih cukup signifikan sehingga diperlukan upaya intervensi, antara lain, melalui peningkatan produktivitas usaha pertanian, peningkatan skala usaha pertanian, dan bantuan sosial untuk dapat memenuhi kebutuhan dasar makanan.

Kata kunci: fies, kerawanan pangan, pertanian, sitasi. 


\section{PENDAHULUAN}

Salah satu isu penting dari tujuan kedua pembangunan berkelanjutan, tanpa kelaparan (no hunger) adalah kejadian kerawanan pangan (food insecurity). Target pertama dari delapan target dalam tujuan ini, yakni Target 2.1 berfokus pada jaminan akses terhadap pangan untuk semua. Melalui pencapaian target ini, kelaparan diharapkan dapat diakhiri pada 2030, khususnya kelompok miskin dan rentan dalam akses terhadap pangan yang aman, cukup, dan bergizi sepanjang tahun (FAO, 2020a). Informasi mengenai sub-populasi yang mengalami kerawanan pangan merupakan hal yang sangat penting untuk mencapai tujuan dan target tersebut.

Food Insecurity Experience Scale (FIES) atau skala pengalaman kerawanan pangan merupakan pengukuran kerawanan pangan yang dikembangkan oleh Organisasi Pangan dan Pertanian Dunia (FAO) melalui Voice of the Hunger Project untuk memperoleh informasi mengenai kejadian kerawanan pangan yang dialami oleh sub-populasi (Cafiero, C. et al., 2016; Saint Ville, A. et al., 2019). Dari pengukuran FIES, indikator Sustainable Development Goals (SDG) 2.1.2, yakni proporsi populasi yang mengalami kerawanan pangan moderat hingga parah dapat dihitung. Proporsi tersebut dihitung berdasarkan total skor jawaban setiap rumah tangga terhadap kedelapan pertanyaan FIES dan peluang kerawanan pangan yang diestimasi dengan Rasch Model (Cafiero, C. et al., 2016, 2018; Smith et al., 2017). Indikator SDG 2.1.2 merupakan komponen penting dalam kemajuan monitoring pencapaian Target 2.1 dan Tujuan 2 Pembangunan Berkelanjutan.

Kerawanan pangan pada dasarnya merupakan variabel laten atau karakteristik yang tidak dapat diukur atau diobservasi secara langsung, seperti perilaku dan kecerdasan. Kerawanan pangan dapat diukur melalui sejumlah manifestasinya yang dapat diamati. Konsep yang mendasari pengukuran keamanan pangan berdasarkan apa yang dialami (experience-based) memiliki sejarah yang panjang yang mengakar pada studi-studi etnografi untuk memahami pengalaman tentang kelaparan. Hasil penelitian di Amerika Serikat memperlihatkan bahwa pengalaman mengenai kerawanan pangan dicirikan oleh ketidakpastian dan kecemasan akses pangan dan perubahan kualitas asupan pangan, seperti asupan pangan yang kurang seimbang dan monoton. Dengan meningkatnya kerawanan pangan, kuantitas pangan yang dikonsumsi juga berkurang, aktivitas makan (meals) terlewatkan, dan pada tingkat yang cukup parah orang tidak makan sama sekali. Hasil penelitian di berbagai negara menyimpulkan bahwa dimensi-dimensi pengalaman kerawanan pangan tersebut berlaku umum pada berbagai latar belakang kultural yang berbeda (FAO, 2020b).

Sejak tahun 2017, Badan Pusat Statistik (BPS) telah menerapkan pengukuran FIES untuk menghitung indikator 2.1.2 dengan menggunakan data hasil Survei Sosial Ekonomi Nasional (SUSENAS) (BPS, 2020a). Proporsi rumah tangga yang mengalami kerawanan pangan moderat hingga parah di Indonesia mencapai 5,42\% pada 2019 (BPS, 2020a). Data SUSENAS merupakan indikator yang dihasilkan hanya mewakili populasi secara umum. Pengukuran FIES yang dikhususkan pada populasi rumah tangga pertanian belum tersedia di Indonesia. Padahal, indikator kerawanan pangan yang lebih spesifik untuk rumah tangga pertanian diperlukan untuk mendukung analisis dan perencanaan kebijakan yang lebih spesifik dan mendalam terkait kerawanan pangan pada rumah 
tangga pertanian. Selain itu, pengukuran FIES yang difokuskan pada rumah tangga pertanian merupakan komponen penting dalam penyusunan indikator SDG 2.4.1, yakni proporsi lahan pertanian di bawah pertanian yang produktif dan berkelanjutan (FAO, 2017; Gennari \& Navarro, 2019). Indikator ini juga sangat penting untuk memonitor pencapaian tujuan 2 pembangunan berkelanjutan.

Untuk pengukuran FIES populasi rumah tangga pertanian, sebuah survei yang secara khusus didedikasikan untuk memotret kejadian kerawanan pangan di rumah tangga pertanian sangat dibutuhkan. Terkait hal ini, BPS menginisiasi Survei Pertanian Terintegrasi (SITASI) yang dapat mengumpulkan informasi untuk perhitungan FIES rumah tangga pertanian. Hal ini sesuai dengan rekomendasi FAO dalam Global Strategy to Improve Agricultural and Rural Statistics (GSARS, 2017). Uji coba survei dilakukan di tiga provinsi pada 2020, yakni Provinsi Jawa Barat, Jawa Timur, dan Nusa Tenggara Barat. Pemilihan ketiga provinsi sebagai lokasi uji coba didasarkan pada keberagaman kegiatan pertanian dan proporsi rumah tangga pertanian di tiga provinsi yang mencakup sekitar $33 \%$ dari total rumah tangga pertanian di Indonesia pada 2018 (BPS, 2018).

Makalah ini bertujuan mengkaji pengukuran FIES pada pelaksanaan SITASI untuk mengestimasi prevalensi kerawanan pangan pada rumah tangga pertanian di Provinsi Jawa Barat, Jawa Timur, dan Nusa Tenggara Barat.

\section{METODE PENELITIAN Pengukuran FIES}

FIES memotret kerawanan pangan pada level individu atau rumah tangga melalui jawaban terhadap sejumlah pertanyaan yang menangkap apa yang dialami oleh individu atau rumah tangga terkait akses pangan yang mencukupi. Daftar delapan pertanyaan yang digunakan dalam pengukuran FIES pada penelitian ini disajikan pada Tabel 1.

Tabel 1.

Delapan Pertanyaan dalam Pengukuran dan Analisis FIES

Dalam setahun terakhir, apakah ada saat di mana?

(1) Anda/ART lainnya khawatir tidak akan memiliki cukup makanan untuk disantap karena kurangnya uang atau sumber daya lainnya? (Worry)

(2) Anda/ART lainnya tidak dapat menyantap makanan sehat dan bergizi karena kurangnya uang atau sumber daya lainnya? (Healthy)

(3) Anda/ART lainnya hanya menyantap sedikit jenis makanan karena kurangnya uang atau sumber daya lainnya? (Fewfood)

(4) Anda/ART lainnya pernah melewatkan makan pada suatu hari tertentu karena kurangnya uang atau sumber daya lainnya? (Skipped)

(5) Anda/ART lainnya makan lebih sedikit daripada seharusnya karena kurangnya uang atau sumber daya lainnya? (Ateless)

(6) Rumah tangga kehabisan makanan karena kurangnya uang atau sumber daya lainnya? (Runout)

(7) Anda/ART lainnya merasa lapar tapi tidak makan karena kurangnya uang atau sumber daya lainnya untuk mendapatkan makanan? (Hungry)

(8) Anda/ART lainnya tidak makan seharian karena kurangnya uang atau sumber daya lainnya? (Whlday)

Sumber: Pedoman SITASI 2020 yang

diadopsi dari Kuesioner Survei Sosial

Ekonomi Nasional Modul KOR 2019

Kedelapan pertanyaan pada Tabel 1 menggambarkan level status kerawanan pangan (FAO, 2020b). Pertanyaan 1-3 mengarah pada kerawanan pangan ringan (light), pertanyaan 4-6 pada kerawanan pangan sedang (moderate), dan pertanyaan 7-8 pada kerawanan pangan parah (severe). Pertanyaan FIES juga merupakan gambaran psikologis apa yang dialami dan dilakukan oleh rumah tangga ketika menghadapi kerawanan pangan (Wambogo, E.A. et al., 2018). 
Untuk menghitung kejadian kerawanan pangan berdasarkan respon rumah tangga terhadap kedelapan pertanyaan tersebut, FIES menggunakan Rasch Model yang didasarkan pada teori respon item (item response theory) (Snyder S. dan Sheehan R., 1992). Secara sederhana, Rasch Model menghubungkan antara respon (jawaban pertanyaan) dan item (butir pertanyaan) (Bond dan Fox, 2015). Keterkaitan ini dianalisis melalui nilai odd ratio dari respon dengan formula berikut:

$$
\begin{aligned}
& \operatorname{Prob}\left(X_{i, j}=1\right) \\
& =\frac{\exp \left(\theta_{i}-\beta_{j}\right)}{1+\exp \exp \left(\theta_{i}-\beta_{j}\right)} \ldots \ldots \ldots \ldots \ldots \ldots
\end{aligned}
$$

di mana $X_{i, j} \in\{0,1\}$ adalah respon dari responden ke- $i$ terhadap item ke-j. Dalam hal ini, $X_{i, j}$ merupakan respon dari setiap responden survei terhadap setiap pertanyaan pada Tabel 1. $X_{i, j}$ akan bernilai 1 jika responden menjawab "ya" untuk item pertanyaan yang ditanyakan dan 0 jika "tidak". $\theta_{i}$ dan $\beta_{j}$ masing-masing adalah parameter responden dan parameter item yang dapat diestimasi menggunakan metode maximum likelihood (MLE) dengan memanfaatkan nilai-nilai $X_{i, j}$ dari jawaban responden.

Rasch Model memberikan dasar untuk memperkirakan parameter keparahan yang terkait dengan item, yaitu berbagai pengalaman yang disebutkan dalam pertanyaan, dan responden sekaligus melakukan uji statistik terhadap kekuatan asosiasi tanggapan terhadap sifat laten (kerawanan pangan) dan goodness of fit. Penggunaan model ini memungkinkan data hasil survei digunakan untuk validasi keandalan ukuran kerawanan pangan. Terkait hal ini, ukuran-ukuran yang digunakan adalah infit untuk melihat performa setiap item pertanyaan, Rasch reliability untuk melihat seberapa besar variasi di dalam populasi yang dijelaskan oleh model pengukuran, dan residual correlation. Kondisi yang diharapkan adalah nilai infit untuk setiap pertanyaan pada Tabel 1 berada pada rentangan antara 0,7 dan 1,3; Rasch reliability > 0,7; dan tidak ada korelasi signifikan yang tersisa di residual (Cafiero, C. et al., 2016, 2018).

\section{Metode Pemilihan Sampel dan Estimasi Populasi}

Sampel dalam penelitian ini adalah rumah tangga pertanian di tiga provinsi lokasi uji coba survei. Sementara itu, responden dalam penelitian ini adalah salah satu anggota rumah tangga pertanian, yang mewakili rumah tangga pada saat wawancara untuk menjawab seluruh pertanyaan FIES terkait kondisi kerawanan pangan rumah tangga. Definisi rumah tangga pertanian adalah rumah tangga yang minimal salah satu anggotanya mengusahakan tanaman pangan, hortikultura, perkebunan, dan atau peternakan selama setahun yang lalu. Pemilihan sampel rumah tangga menggunakan teknik pemilihan sampel acak bertahap (multistage random sampling).

Tahapan pemilihan sampel diawali dengan memilih kabupaten di setiap provinsi secara probability proportional to size (PPS) dengan estimasi jumlah rumah tangga pertanian hasil Survei Pertanian Antar Sensus (SUTAS 2018) sebagai size. Setelah itu, sampel blok sensus dipilih di setiap kabupaten terpilih dengan teknik PPS systematic. Tahapan terakhir adalah memilih sampel rumah tangga pertanian di masingmasing blok sensus terpilih dengan teknik systematic sampling.

Jumlah sampel rumah tangga pertanian di setiap blok sensus ditentukan dengan formula sebagai berikut:

$m=\frac{m_{0} M}{m_{0}+(M+1)}$ 


$$
m_{0}=\frac{(Z \alpha / 2 \sigma)^{2}}{e^{2}} \operatorname{deff} \frac{1}{r}
$$

dimana

$m$ : jumlah sampel rumah tangga minimum di setiap blok sensus

M : estimasi total rumah tangga pertanian dari hasil SUTAS (2018)

$e \quad$ : margin of error

$\sigma^{2}$ : variasi persentase perempuan di dalam rumah tangga pertanian

deff: design effect

Penerapan metode penarikan sampel berpeluang (probability sampling method) memungkinkan estimasi kejadian kerawanan pangan, baik dalam persentase maupun jumlah absolut, pada populasi rumah tangga pertanian di tiga provinsi dapat diestimasi dengan menggunakan penimbang survei (sampling weight) (Cafiero, C. et al., 2018).

\section{Metode Analisis}

Kajian FIES dalam penelitian ini mengacu pada FAO (2020b). Tahapan kajian diawali dengan estimasi parameter, yakni perhitungan keparahan kerawanan pangan terkait dengan setiap item dan setiap rumah tangga. Selanjutnya dilakukan validasi statistik untuk memeriksa apakah pengukuran kerawanan pangan yang dilakukan valid, yakni cukup bisa diandalkan untuk kebijakan dan tujuan penelitian. Setelah itu, penghitungan ukuran kerawanan pangan dilakukan, yang terdiri dari peluang rumah tangga mengalami kerawanan pangan moderat dan parah berdasarkan respon jawaban terhadap pertanyaan FIES dan prevalensi kerawanan pangan moderat dan parah di dalam populasi. Peluang kerawanan pangan dihitung untuk setiap skor total yang merupakan agregasi nilai $X_{i, j}$ untuk setiap item pertanyaan. Hal ini berarti bahwa skor total setiap rumah tangga untuk kedelapan pertanyaan dapat bernilai $0,1,2,4,5,6,7$ atau 8. Tahapan terakhir adalah menghitung subindikator ke-10 indikator SDGs 2.4.1, yakni proporsi lahan pertanian yang dikelola oleh rumah tangga dengan kejadian kerawanan pangan.

Melalui tahapan kajian ini dapat dihasilkan dua indikator penting, yakni proporsi rumah tangga pertanian di setiap provinsi lokasi survei yang mengalami kerawanan pangan moderat hingga parah $\left(F_{\text {mod }+ \text { sev }}\right)$ dan proporsi rumah tangga pertanian yang mengalami kerawanan pangan parah $\left(F_{\text {sev }}\right)$. Selain itu, gambaran proporsi lahan pertanian yang tidak berkelanjutan karena dikelola oleh rumah tangga dengan status kerawanan pangan parah juga dapat diperoleh.

\section{HASIL DAN PEMBAHASAN Realisasi Survei}

Jumlah sampel dalam uji coba survei mencapai 1.300 rumah tangga yang tersebar di tiga provinsi, yakni Jawa Barat (648 sampel), Jawa Timur (441 sampel), dan Nusa Tenggara Barat (211 sampel) (Tabel 2). Dari seluruh sampel, terdapat 163 sampel yang tidak menjawab sebagian atau seluruh pertanyaan FIES dengan sebaran sebanyak 76 sampel di Jawa Barat, 59 sampel di Jawa Timur, dan 28 sampel di Nusa Tenggara Barat. Hal ini disebabkan karena ada keengganan untuk menjawab pertanyaan survei atau responden yang mewakili rumah tangga tidak tahu jawaban dari pertanyaan yang disampaikan oleh pewawancara. Sementara itu, jumlah sampel merespon secara lengkap seluruh pertanyaan FIES sebanyak 1.137 sampel. Penelitian ini hanya menganalisis sampel yang menjawab secara lengkap semua pertanyaan FIES tersebut. Dengan memperhitungkan penimbang survei (sampling weight), estimasi rumah tangga yang merespon pertanyaan FIES 
secara lengkap mewakili sebanyak 10,14 juta rumah tangga pertanian di tiga provinsi lokasi uji coba survei. Jumlah rumah tangga yang merespon secara lengkap pertanyaan FIES di Provinsi Jawa Barat mewakili 5,41 juta rumah tangga, Jawa Timur 4,48 juta rumah tangga, dan Nusa Tenggara Barat 0,25 juta rumah tangga. Sementara itu, jumlah rumah tangga yang tidak menjawab sebagian atau seluruh pertanyaan FIES mewakili sebanyak 1,49 juta rumah tangga pertanian di tiga provinsi. Jika dilihat menurut provinsi, sebagian besar kejadian rumah tangga tidak menjawab sebagian atau seluruh pertanyaan FIES (missing) terjadi di Provinsi Jawa Barat. Namun demikian, karena proporsi non-respon relatif kecil dibandingkan dengan total sampel, hal ini tidak terlalu berdampak terhadap pengukuran dan analisis FIES dalam penelitian ini.

\section{Tabel 2.}

Jumlah Sampel yang Merespon Pertanyaan FIES Menurut Jenis Respon dan Provinsi

\begin{tabular}{lrrrr}
\hline $\begin{array}{c}\text { Jenis } \\
\text { respon }\end{array}$ & $\begin{array}{r}\text { Jawa } \\
\text { Barat }\end{array}$ & $\begin{array}{r}\text { Jawa } \\
\text { Tmur }\end{array}$ & NTB & Total \\
\hline $\begin{array}{l}\text { Jawaban } \\
\text { lengkap }\end{array}$ & 572 & 382 & 183 & 1.137 \\
$\begin{array}{l}\text { Jawaban } \\
\text { missing }\end{array}$ & 76 & 59 & 28 & 163 \\
$\begin{array}{l}\text { Total } \\
\text { sampel }\end{array}$ & 648 & 441 & 211 & 1.300 \\
\hline
\end{tabular}

Sumber: Hasil Analisis Data

Gambar 1 menyajikan proporsi rumah tangga yang menjawab "ya" untuk setiap item pertanyaan pada Tabel 1. Dapat dilihat bahwa proporsi rumah tangga pertanian yang menjawab "ya" untuk item pertanyaan Worry (cemas) di tiga provinsi lokasi survei mencapai $6,6 \%$, paling tinggi dibandingkan kategori pertanyaan lainnya. Hal ini sejalan dengan teori dalam analisis FIES. Dalam keadaan normal atau awal dari keadaan rawan pangan, secara psikologis yang pertama kali muncul adalah rasa khawatir tidak memiliki cukup makanan yang dicerminkan oleh pertanyaan pertama.

Idealnya, proporsi akan semakin mengecil seiring dengan meningkatnya tingkat keparahan yang dicerminkan oleh respon rumah tangga. Dengan kata lain, proporsi yang menjawab "ya" mestinya semakin mengecil dari pertanyaan pertama (terbesar) ke pertanyaan kedelapan (terkecil). Menurut Ballard et al (2013), setiap item pertanyaan FIES memperlihatkan situasi yang berbeda berdasarkan tingkat kerawanan pangan yang dialami rumah tangga. Karena itu, persentase jawaban "ya" untuk setiap item pertanyaan FIES akan semakin menurun mulai dari pertanyaan yang pertama hingga pertanyaan yang kedelapan.

Ada anomali yang ditunjukkan oleh proporsi yang menjawab "ya" untuk pertanyaan Skipped $(0,44 \%)$ yang lebih rendah dibanding proporsi jawaban "ya" untuk pertanyaan Ateless (1,23 \%). Hal yang sama juga terjadi untuk item pertanyaan Hungry $(0,09 \%)$ yang memiliki proporsi lebih rendah dibanding item pertanyaan Whlday $(0,18 \%)$. Hal ini mengindikasikan adanya ketidakkonsistenan responden dalam melaporkan pengalaman yang dialami oleh rumah tangganya kepada petugas pencacah saat wawancara (Herlina, H. et al., 2020). Maksud dari konsistensi di sini adalah jika suatu item pertanyaan direspon "ya, semua item pertanyaan yang menunjukkan tingkat keparahan yang lebih rendah (kurang parah) juga akan dijawab "ya" (Cafiero et al., 2016). Sebagai contoh, jika suatu rumah tangga menjawab "ya" untuk pertanyaan yang ke-4, rumah tangga tersebut mestinya juga akan menjawab "ya" untuk item pertanyaan ke-1 sampai dengan ke-3. Meskipun terjadi anomali pada pertanyaan 
Skipped dan Hungry, hal ini tidak mempengaruhi validitas dari pengukuran FIES yang dilakukan dalam penelitian ini.

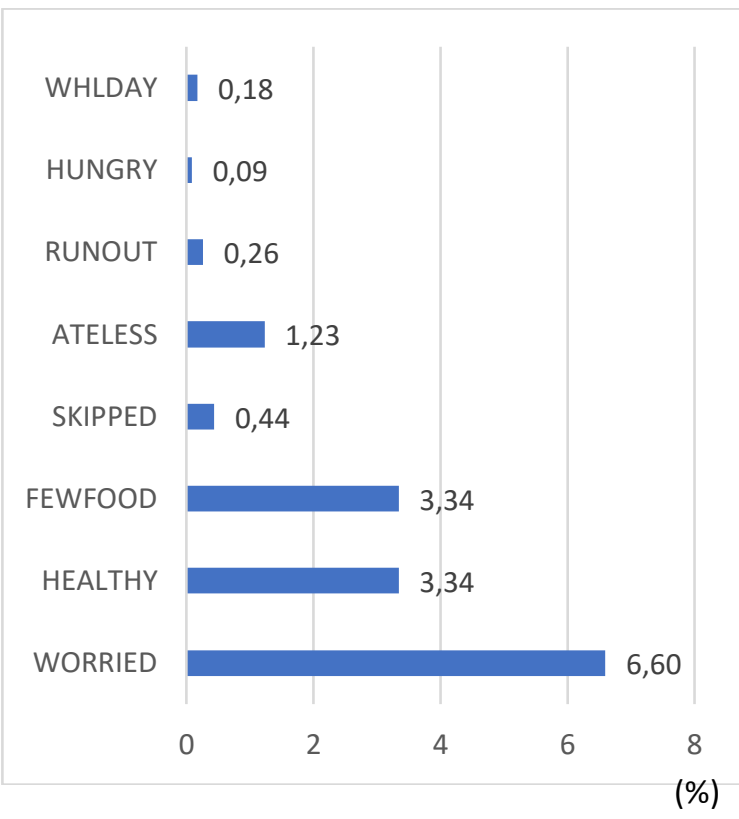

Gambar 1. Persentase Rumah Tangga yang Menjawab "Ya" untuk Setiap Item Pertanyaan FIES

Sumber: Hasil Analisis Data

Anomali seperti ini dapat disebabkan kurangnya pemahaman responden terhadap maksud pertanyaan yang ditanyakan oleh pewawancara. Pada saat yang sama, pewawancara bisa jadi tidak maksimal dalam menggali informasi dan memahamkan responden terhadap maksud dari pertanyaan yang ditanyakan. Karena itu, anomali ini harus menjadi perhatian dan bahan evaluasi bagi pelaksanaan survei berikutnya. Terkait hal ini, salah satu rekomendasi dari FAO (2020c) adalah dengan mengalokasikan waktu yang lebih lama pada saat pelaksanaan pelatihan petugas ketika membahas mengenai pertanyaan-pertanyaan FIES, khususnya terkait item pertanyaan yang secara sekilas seperti menanyakan hal yang sama. Dengan demikian, baik pencacah maupun responden dapat memahami dan membedakan maksud setiap pertanyaan dengan baik.

\section{Estimasi Paramater Keparahan dan Validitas Statistik}

Hasil estimasi parameter keparahan (severity), infit, dan outfit untuk setiap item pertanyaan FIES disajikan pada Tabel 3. Semua item pertanyaan memiliki nilai infit pada rentang yang diharapkan, yakni antara 0,81 dan 1,25 . Hal ini menunjukkan bahwa semua item pertanyaan dapat digunakan untuk pengukuran kerawanan pangan atau berkinerja baik. Nilai infit yang berada pada rentang 0,7 sampai 1,3 menunjukkan terpenuhinya asumsi unidimensi atau dengan kata lain pengukuran kerawanan pangan dalam penelitian ini telah memenuhi asumsi unidimensi sesuai yang diharapkan (Ballard et al., 2013; Cafiero et al., 2016) .

Nilai parameter keparahan untuk setiap item (severity), setelah dikalibrasi dengan skala referensi global dengan mengikuti rekomendasi FAO (Cafiero, C. et al., 2018), berada pada rentang $-1,8$ sampai 2,9 . Hanya item Whlday yang nilai parameter keparahannya di luar rentang tersebut, yakni sebesar 2,9. Menurut Hambelton et al. (1991), skala parameter keparahan yang ideal berada pada rentang -2,0 sampai 2,0. Skala yang mendekati -2,0 menunjukkan bahwa item pertanyaan mudah, sementara skala yang mendekati 2,0 menunjukkan bahwa item tersebut sulit. Hal ini berarti bahwa item pertanyaan terakhir nampaknya harus menjadi fokus perhatian dalam penyempurnaan survei selanjutnya. Petugas pencacah harus mampu menjelaskan dengan baik maksud pertanyaan kepada responden agar dapat dipahami dengan baik.

Nilai outfit memperlihatkan bahwa item Hungry dan Whlday memiliki nilai outfit yang lebih besar dari 2 (Tabel 3). Nilai outfit $>2$ memperlihatkan bahwa respon jawaban untuk kedua item pertanyaan tersebut cenderung tidak menentu atau pencilan. Namun demikian, kondisi ini dapat 
diabaikan karena persentase jawaban "ya" untuk kedua item pertanyaan kurang dari 25 $\%$ (Nord, 2014). Persentase respon "ya" untuk kedua item pertanyaan masing-masing hanya sebesar $0,09 \%$ dan $0,18 \%$ (Gambar 1). Temuan ini mengkonfirmasi bahwa rumah tangga pertanian dengan kecenderungan kerawanan pangan parah adalah sesuatu yang jarang terjadi. Dengan kata lain, dua item pertanyaan terakhir yang mengarah pada kerawanan pangan parah jarang dialami oleh rumah tangga pertanian.

\section{Tabel 3.}

Hasil Estimasi Parameter Keparahan, Infit, dan Outfit Untuk Setiap Item Pertanyaan FIES

\begin{tabular}{lrrr}
\hline \multicolumn{1}{c}{ Item } & Severity & infit & Outfit \\
\hline Worry & $-1,8$ & 1,08 & 1,11 \\
Healthy & $-1,3$ & 0,83 & 0,80 \\
Fewfood & $-1,7$ & 0,85 & 0,84 \\
Skipped & 0,5 & 1,19 & 1,37 \\
Ateless & $-0,5$ & 0,82 & 0,76 \\
Runout & 0,8 & 0,81 & 0,53 \\
Hungry & 1,2 & 1,14 & 3,31 \\
Whlday & 2,9 & 1,25 & 3,23 \\
\hline \multicolumn{2}{r}{ Sumber }
\end{tabular}

Sumber: Hasil Analisis Data

Nilai Rasch realiability sebesar 0,77 menunjukkan bahwa data yang digunakan cukup valid untuk dianalisis atau item-item pertanyaan FIES secara keseluruhan sudah baik dalam mengukur kerawanan pangan rumah tangga pertanian di tiga provinsi uji coba survei. Total variasi di dalam populasi rumah tangga pertanian di tiga provinsi lokasi uji coba juga dapat dijelaskan dengan baik. Hal ini tercermin dari scree plot yang memperlihatkan bahwa tidak ada korelasi yang tersisa di residual model (Gambar 2). Sebagian besar variasi pengukuran FIES dalam pelaksanaan SITASI ditangkap oleh pertanyaan 1, 2, dan 3. Variasi pengukuran untuk empat pertanyaan lainnya relatif rendah dibandingkan dengan tiga pertanyaan tersebut. Hal ini sejalan dengan keragaman jawaban rumah tangga terhadap kedelapan pertanyaan FIES pada Gambar 1.

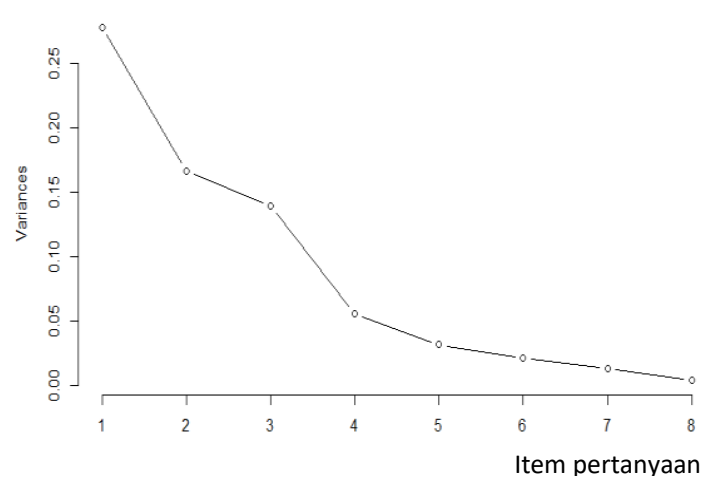

Gambar 2. Scree Plot Hasil Pengolahan Data

Sumber: Hasil Analisis Data

Korelasi residual antar item pertanyaan FIES lebih kecil dari |0,40| (Tabel 4). Hal ini memperlihatkan bahwa item-item pertanyaan FIES dalam uji coba survei saling bebas atau independen (Nord, 2014). Dengan demikian jawaban rumah tangga untuk suatu pertanyaan FIES dalam uji coba survei tidak berkorelasi atau tergantung pada jawaban pertanyaan lainnya.

Hasil estimasi parameter keparahan dan pemeriksaan validitas statistik melalui nilai Rasch reliability, infit, outfit, dan korelasi residual secara umum memperlihatkan bahwa pengukuran FIES dapat diterapkan pada populasi rumah tangga pertanian melalui pelaksanaan SITASI. Temuan ini sejalan dengan Herlina, H. et al. (2020) untuk pengukuran FIES pada rumah tangga umum (pertanian dan non pertanian) dengan menggunakan data SUSENAS.

\section{Peluang dan Prevalensi Kerawanan Pangan}

Tabel 5 menyajikan hasil perhitungan proporsi rumah tangga pertanian, peluang rumah tangga pertanian mengalami rawan pangan moderat hingga parah, dan peluang rumah tangga mengalami rawan pangan 
parah menurut total skor (raw score) jawaban kedelapan pertanyaan FIES. Sebagian besar rumah tangga di tiga provinsi uji coba memiliki total skor 0, yakni dengan proporsi mencapai $93,06 \%$ atau sekitar 9.445.053 rumah tangga dari 10.149.920 rumah tangga pertanian di tiga provinsi. Hal ini memperlihatkan bahwa sebagian besar rumah tangga pertanian di tiga provinsi sama sekali tidak pernah mengalami hal-hal yang mengarah pada kerawanan pangan selama setahun yang lalu atau dengan kata lain sebagian besar rumah tangga tidak mengalami apa yang ditanyakan pada kedelapan pertanyaan FIES. Proporsi yang tinggi ini berkonsekuensi kecilnya peluang rumah tangga pertanian untuk mengalami kerawanan pangan, baik moderat maupun parah.

Proporsi rumah tangga pertanian yang memiliki skor mentah 1 mencapai 456.536 rumah tangga atau sekitar $4,50 \%$ dari total rumah tangga pertanian di tiga provinsi lokasi uji coba. Hal ini berarti bahwa ada 456.536 rumah tangga yang mengalami salah satu dari delapan pertanyaan FIES. Proporsi rumah tangga yang mengalami tiga dari delapan pertanyaan FIES juga relatif besar, yakni mencapai $1,10 \%$ atau sekitar 110.313 rumah tangga pertanian. Temuan menarik dalam penelitian ini adalah jumlah rumah tangga pertanian yang mengalami kedelapan pertanyaan FIES selama setahun yang lalu mencapai $0,18 \%$ atau sekitar 18.115 rumah tangga pertanian. Hal ini menunjukkan bahwa persoalan kerawanan pangan yang mengarah pada tingkatan parah juga eksis di rumah tangga pertanian yang notabene merupakan penghasil pangan itu sendiri. Kejadian ini nampaknya terjadi pada rumah tangga pertanian yang termasuk dalam small scale food producer atau petani skala kecil yang memiliki produksi relatif kecil dan hanya mencukupi untuk kebutuhan sehari-hari (subsisten). Rumah tangga petani skala kecil ditentukan berdasarkan dua kriteria, yaitu ukuran fisik dan ekonomi suatu usaha pertanian, yang mencakup luas lahan yang dikelola, jumlah ternak yang dipelihara, dan pendapatan total produksi pertanian. Berdasarkan kriteria tersebut ditentukan ambang batas $40 \%$ distribusi terbawah. Dalam penelitian ini, rumah tangga petani skala kecil dicirikan oleh penguasaan lahan pertanian yang relatif sempit (kurang dari 0,16 ha), jumlah ternak yang diusahakan kurang dari 0,61 unit ternak tropikal (tropical livestock unit), dan nilai pendapatan dari usaha pertanian yang relatif kecil, yakni kurang dari US\$1.044,169 dalam Purchasing Power Parity (PPP) per tahun (BPS, 2020b). Mereka adalah kelompok yang sangat rentan terhadap berbagai shock yang mengganggu produksi pertanian, seperti banjir, kekeringan, yang merupakan dampak dari perubahan iklim, dan kelangkaan input produksi (Harvey et al., 2018; Donatti et al., 2019; Mbuli et al., 2021).

Beberapa studi juga mengkonfirmasi bahwa petani skala kecil merupakan kelompok miskin yang dicirikan dengan kegiatan pertanian yang ditujukan untuk memenuhi kebutuhan sehari-hari (subsisten) dan produktivitas usaha tani yang rendah (Rapsomanikis G., 2015; Hasselberg J, 2017; Olusayu et al., 2019).

Peluang mengalami kerawanan pangan, baik moderat maupun parah, akan meningkat seiring dengan meningkatnya skor mentah (Tabel 5). Sebagai contoh rumah tangga pertanian dengan skor mentah satu hanya memiliki peluang sebesar 0,028 untuk mengalami kerawanan pangan moderat atau parah. Sementara itu, rumah tangga pertanian dengan skor mentah lebih besar dari empat memiliki peluang mendekati satu untuk mengalami kerawanan 
pangan moderat hingga parah. Hasil perhitungan juga memperlihatkan bahwa peluang rumah tangga pertanian untuk mengalami kerawanan pangan pada tingkat yang parah sangat kecil. Hanya ketika skor mentah mencapai 7 atau 8, suatu rumah tangga pertanian memiliki peluang yang cukup besar untuk mengalami kerawanan pangan pada tingkat yang parah, yakni lebih besar dari 0,5. Adapun peluang rumah tangga pertanian di tiga provinsi lokasi survei untuk mengalami kerawanan pangan pada tingkat yang parah ketika skor mentah mencapai 7 dan 8 masing-masing adalah sebesar 0,546 dan 0,667 (Tabel 5).

Tabel 4.

Korelasi Residual Item Pertanyaan FIES

\begin{tabular}{cccccccc}
\hline $\begin{array}{c}\text { Raw } \\
\text { score }\end{array}$ & 2 & 3 & 4 & 5 & 6 & 7 & 8 \\
\hline 1 & 0,05 & 0,02 & $-0,17$ & 0,02 & $-0,03$ & $-0,19$ & $-0,26$ \\
2 & & 0,27 & $-0,03$ & 0,12 & 0,04 & $-0,15$ & $-0,20$ \\
3 & & & $-0,04$ & 0,11 & 0,03 & $-0,14$ & $-0,20$ \\
4 & & & & $-0,01$ & $-0,05$ & $-0,06$ & $-0,08$ \\
5 & & & & & 0,39 & $-0,11$ & $-0,15$ \\
6 & & & & & & $-0,05$ & $-0,07$ \\
7 & & & & & & & $-0,05$ \\
\hline
\end{tabular}

Sumber: Hasil Analisis Data

Tabel 5.

Proporsi Rumah Tangga, Jumlah Absolut, Peluang Rawan Pangan Moderat atau Parah, dan Peluang Rawan Pangan Parah Menurut Nilai Skor Mentah (Raw Score)

\begin{tabular}{cllll}
\hline & $\begin{array}{l}\text { Proporsi } \\
\text { rumah tangga } \\
\text { Rertanian score } \\
(\%)\end{array}$ & $\begin{array}{l}\text { Jumlah } \\
\text { rumah tangga } \\
\text { pertanian } \\
\text { (Weighted })\end{array}$ & $\begin{array}{l}\text { Peluang rawan } \\
\text { pangan } \\
\text { moderat atau } \\
\text { parah }\end{array}$ & $\begin{array}{l}\text { Peluang } \\
\text { rawan } \\
\text { pangan } \\
\text { parah }\end{array}$ \\
\hline 0 & 93,06 & 9.445 .053 & 0 & 0 \\
1 & 4,50 & 456.536 & 0,028 & 0,000 \\
2 & 0,79 & 80.401 & 0,116 & 0,000 \\
3 & 1,10 & 110.313 & 0,376 & 0,000 \\
4 & 0,24 & 24.149 & 0,719 & 0,001 \\
5 & 0,15 & 15.353 & 0,928 & 0,012 \\
6 & 0 & 0 & 0,994 & 0,192 \\
7 & 0 & 0 & 0,997 & 0,546 \\
8 & 0,18 & 18.115 & 0,995 & 0,667 \\
\hline
\end{tabular}

Sumber: Hasil Analisis Data

Kejadian kerawanan pangan pada rumah tangga pertanian di tiga provinsi lokasi uji coba survei dihitung menggunakan data pada Tabel 5. Prevalensi kerawanan pangan menunjukkan seberapa banyak rumah tangga pertanian di tiga provinsi yang 
mengalami kerawanan pangan untuk setiap 100 rumah tangga pertanian. Prevalensi kerawanan pangan dipilah menjadi kerawanan pangan moderat hingga parah (moderat + parah) dan kerawanan pangan parah (Cafiero et al., 2018). Proporsi rumah tangga pertanian yang mengalami kerawanan pangan moderat hingga parah dan kerawanan pangan parah di tiga provinsi lokasi uji coba survei dapat dilihat pada Tabel 6.

Tabel 6.

Proporsi Rumah Tangga yang Mengalami Kerawanan Pangan Menurut Provinsi dan Tingkat Kerawanan Pangan

\begin{tabular}{lcr}
\hline \multicolumn{1}{c}{ Provinsi } & $\begin{array}{c}\text { Moderat } \\
\text { hingga } \\
\text { parah }(\%)\end{array}$ & \multicolumn{1}{c}{$\begin{array}{c}\text { Parah } \\
(\%)\end{array}$} \\
\hline Jawa Barat & 0,67 & 0,07 \\
Jawa Timur & 1,49 & 0,18 \\
Nusa Tenggara & & \\
Barat & 3,90 & 0,01 \\
Total 3 provinsi & 1,12 & 0,12 \\
\hline
\end{tabular}

Sumber: Hasil Analisis Data

Secara total, tingkat prevalensi kerawanan pangan moderat hingga parah hanya sebesar $1,12 \%$ dari total rumah tangga pertanian di tiga provinsi. Hal ini berarti bahwa pada setiap 100 rumah tangga pertanian di tiga provinsi lokasi uji coba hanya satu rumah tangga yang mengalami kerawanan pangan moderat atau parah. Sementara itu, prevalensi kerawanan pangan parah di tiga provinsi hanya sebesar $0,12 \%$ dari total rumah tangga pertanian. Hal ini mudah dipahami mengingat populasi survei adalah rumah tangga pertanian yang merupakan produsen pangan. Meskipun relatif rendah, perlu diperhatikan bahwa estimasi populasi dengan menggunakan penimbang survei menunjukkan, secara absolut prevalensi kerawanan pangan moderat hingga parah setara dengan 113.163 rumah tangga sementara prevalensi kerawanan pangan parah setara dengan 12.276 rumah tangga. Hal ini tentu patut menjadi perhatian serius para pengambil kebijakan untuk memastikan seluruh rakyat Indonesia memiliki akses pangan yang cukup dan bergizi. Hal ini juga merupakan isu penting karena terkait dengan produktivitas dan keberlanjutan sektor pertanian kita.

Mereka yang mengalami kerawanan pangan moderat hingga parah dapat dipastikan pernah mengalami salah satu kejadian yang mengarah pada kerawanan pangan berikut selama setahun yang lalu karena kurangnya uang atau sumber daya lainya, seperti melewatkan makan pada suatu hari tertentu, makan lebih sedikit dari biasanya, atau kehabisan makanan. Sementara itu, rumah tangga pertanian yang mengalami kerawanan pangan parah dipastikan minimal salah satu anggota rumah tangganya pernah mengalami salah satu kejadian berikut selama setahun yang lalu karena kurangnya uang atau sumber daya lainnya: merasa lapar tapi tidak makan atau tidak makan selama seharian. Hal ini didasarkan pada asumsi bahwa urutan pertanyaan FIES dirancang untuk menangkap tingkat kerawanan pangan yang semakin meningkat. Seperti telah diuraikan sebelumnya, pertanyaan 4-6 mengarah pada kerawanan pangan sedang (moderate) dan pertanyaan 7-8 mengarah pada kerawanan pangan parah (severe) (Wambogo, E.A. et al., 2018).

Nampaknya, rumah tangga yang mengalami kerawanan pangan, baik sedang ataupun parah adalah rumah tangga dengan skala usaha pertanian yang relatif kecil (small scale food producer) dan berpendapatan rendah, yakni kurang dari US\$1.044,169 PPP dalam setahun (BPS, 2020b). 
Prevalensi tertinggi kerawanan pangan moderat hingga parah pada rumah tangga pertanian terjadi di Provinsi Nusa Tenggara Barat yang mencapai 3,90\%. Hal ini berarti untuk setiap 100 rumah tangga pertanian di Nusa Tenggara Barat terdapat 4 rumah tangga yang mengalami kerawanan pangan moderat atau parah. Prevalensi tersebut setara dengan 9,8 ribu rumah tangga. Angka ini diperoleh dengan mengalikan angka prevalensi dengan estimasi total populasi rumah tangga pertanian di Provinsi Nusa Tenggara Barat, yang sebanyak 0,25 juta rumah tangga. Sementara prevalensi tertinggi kerawanan pangan pada tingkat yang parah terjadi di Provinsi Jawa Timur yang mencapai $0,18 \%$ atau setara dengan 8,2 ribu rumah tangga. Sementara itu, Provinsi Jawa Barat memiliki prevalensi tingkat kerawanan pangan yang cukup rendah dibandingkan dua provinsi lainnya. Prevalensi tingkat kerawanan pangan pada tingkat moderat hingga parah di Jawa Barat merupakan yang paling rendah dibandingkan Jawa Timur dan Nusa Tenggara Barat, yaitu sebesar $0,67 \%$ atau setara dengan 36,3 ribu rumah tangga. Hal ini memperlihatkan bahwa di tiga provinsi lokasi uji coba, sebagian rumah tangga pertanian merupakan kelompok rentan dengan skala produksi pertanian yang relatif rendah. Intervensi dan komitmen dari pemerintah daerah sangat dibutuhkan untuk mengatasi masalah tersebut.

kejadian kerawanan pangan merupakan fenomena petani skala kecil dengan produktivitas yang rendah dan sangat rentan terhadap berbagai guncangan yang mempengaruhi produksi pertanian. Oleh karena itu, intervensi kebijakan harus difokuskan pada kelompok ini. Setidaknya, ada tiga intervensi kebijakan yang dapat dilakukan, yakni peningkatan produktivitas usaha pertanian melalui bantuan sarana dan prasarana produksi (saprodi) serta pendampingan usaha tani, peningkatan skala usaha pertanian melalui ekstensifikasi, dan bantuan sosial untuk memastikan kelompok petani kecil dapat memenuhi kebutuhan dasarnya, terutama makanan, ketika terjadi gangguan produksi akibat bencana alam dan serangan hama dan organisme pengganggu tanaman (OPT). Dalam implementasinya, ketiga intervensi tersebut membutuhkan dukungan data petani skala kecil by name by address agar intervensi yang dilakukan efektif dan tepat sasaran.

\section{Sub Indikator ke-10 Indikator SDG 2.4.1}

Dalam perhitungan indikator SDG 2.4.1, lahan pertanian dikategorikan tidak berkelanjutan jika peluang rumah tangga petani yang mengelola lahan tersebut menjadi rawan pangan parah lebih besar dari 0,5 (BPS, 2020b). Dengan menggunakan kriteria ini, hasil perhitungan lanjutan menunjukkan bahwa sebagian besar lahan pertanian di tiga provinsi lokasi uji coba survei dikategorikan berkelanjutan $(99,66 \%)$ terkait status kerawanan rumah tangga pertanian yang mengelola lahan tersebut. Proporsi lahan pertanian yang terkategori tidak berkelanjutan karena dikelola oleh rumah tangga pertanian dengan status kerawanan pangan parah hanya sebesar $0,21 \%$ atau setara dengan 7,81 ribu ha.

Sebagian besar lahan tersebut terdapat di Provinsi Jawa Timur, yakni seluas 6,29 ribu ha kemudian disusul Provinsi Jawa Barat seluas 1,51 ribu ha. Hal ini mengindikasikan bahwa secara rata-rata rumah tangga pertanian yang mengalami kerawanan pangan parah, yakni sebanyak $0,12 \%$ dari total rumah tangga pertanian atau setara dengan 12,28 ribu rumah tangga (Tabel 6), mengelola lahan pertanian yang relatif sempit, yakni kurang dari satu hektar. Hasil penelitian ini juga menguatkan dugaan 
sebelumnya bahwa kejadian kerawanan pangan pada populasi rumah tangga pertanian merupakan fenomena petani kecil atau small scale food producer.

\section{SIMPULAN}

Pengukuran FIES dapat dilakukan pada rumah tangga pertanian melalui pelaksanaan SITASI. Hal ini ditunjukkan oleh hasil perhitungan parameter keparahan dan ukuran-ukuran validitas statistik, yakni Rasch reliability, infit, outfit, dan residual correlation. Semua asumsi yang mendasari validitas pengukuran FIES terpenuhi. Meskipun demikian, pemahaman responden dan petugas pengumpul data terhadap maksud dari setiap pertanyaan FIES harus menjadi perhatian untuk ditingkatkan pada pelaksanaan survei selanjutnya, khususnya pada item-item pertanyaan yang menangkap pengalaman kerawanan pangan parah ( 7 dan 8). Dengan demikian, kualitas data dapat ditingkatkan.
Prevalensi rawan pangan moderat hingga parah di tiga provinsi relatif kecil. Hal ini menunjukkan bahwa kejadian kerawanan pangan relatif jarang terjadi pada populasi rumah tangga pertanian. Secara absolut jumlah rumah tangga yang mengalami rawan pangan moderat hingga parah dan parah cukup signifikan. Karena itu, isu kerawanan pangan tetap relevan pada rumah tangga pertanian. Intervensi kebijakan yang dapat dilakukan, antara lain adalah peningkatan produktivitas usaha pertanian melalui bantuan sarana dan prasarana produksi (saprodi) serta pendampingan usaha tani, peningkatan skala usaha pertanian melalui ekstensifikasi, dan bantuan sosial untuk memastikan kelompok petani kecil dapat memenuhi kebutuhan dasarnya, terutama makanan. Intervensi tersebut membutuhkan dukungan data target sasaran (by name by adress) agar efektif dan tepat sasaran.

\section{DAFTAR PUSTAKA}

Ballard, T. J., Kepple, A. W., \& Cafiero, C. (2013). The food insecurity experience scale: development of a global standard for monitoring hunger worldwide. Rome: FAO.

Bond, T., \& Fox, C. M. (2015). Applying the Rasch model: Fundamental measurement in the human sciences. Routledge.

BPS. (2018). Hasil Survei Pertanian Antar Sensus (SUTAS) 2018. Jakarta, BPS.

BPS. (2020a). Indikator Tujuan Pembangunan Berkelanjutan Indonesia 2020. Jakarta, BPS

BPS. (2020b). Indikator Tujuan Pembangunan Berkelanjutan Sektor Pertanian 2020. Jakarta, BPS.

BPS. (2020c). Buka Pedoman Pencacahan Survei Pertanian Terintegrasi 2020. Jakarta, BPS.

Cafiero, C., Nord, M., Viviani, S., Del Grossi, M. E., Ballard, T., Kepple, A., \& Nwosu, C. (2016). Methods for estimating comparable prevalence rates of food insecurity experienced by adults throughout the world. Rome (IT): Food and Agriculture Organization of the United Nations.

Cafiero, C., Viviani, S., \& Nord, M. (2018). Food security measurement in a global context: The food insecurity experience scale. Measurement, 116, 146-152. 
Donatti, C. I., Harvey, C. A., Rodriguez, M. R., Vignola, R., \& Rodriguez, C. M. (2019). Vulnerability of smallholder farmers to climate change in Central America and Mexico: current knowledge and research gaps, Climate and Development, 11:3, 264286, DOI: 10.1080/ 17565529.2018.1442796.

FAO. (2017). SDG Indicator 2.4.1. Percentage of Agricultural Area under Productive and Sustainable Agriculture. http://www.fao.org/3/CA2639EN/ca2639en.pdf diakses pada 10 Maret 2021.

FAO, IFAD, UNICEF, WFP and WHO. (2020a). The State of Food Security and Nutrition in the World 2020. Transforming food systems for affordable healthy diets. Rome, FAO. https://doi.org/10.4060/ca9692en.

FAO.(2020b). The Food Insecurity Experience Scale: Measuring food insecurity through people's experiences: http://www.fao.org/in-action/voices-of-the-hungry/usingfies/en/ diakses pada 8 Februari 2021.

FAO.(2020c). Implementing the Food Insecurity Experience Scale (FIES) in surveys: Choosing a survey vehicle: http://www.fao.org/in-action/voices-of-the-hungry/usingfies/en/ diakses pada 8 Februari 2021.

Gennari, P. \& Navarro, D.K. (2019). The Challenge of Measuring Agricultural Sustainability in All Its Dimensions, Journal of Sustainability Research, doi: 10.20900/jsr20190013.

Global Strategy to Improve Agricultural and Rural Statistics (GSARS). (2017). Handbook on the Agricultural Intgerated Survey. Rome: FAO.

Hambleton, R. K., Swaminathan, H., \& Rogers, H. J. (1991). Fundamentals of item response theory. Sage.

Harvey, C.A., Saborio-Rodríguez, M., Martinez-Rodríguez, M.R., Viguera, B., Guadarrama, A.C., Vignola, R., \& Alpizar, F. (2018). Climate change impacts and adaptation among smallholder farmers in Central America. Agriculture and Food Security (2018) $7: 57$

Hasselberg J. (2017). How can poverty be reduced among small-scale farmers in the highlands of western Cameroon? Ghana Journal of Geography Vol. 9(1), 2017 pages 42-66.

Herlina, H., Sartono, B., \& Susetyo, B. (2020). Kajian Validitas Instrumen Pengukuran Skala Pengalaman Kerawanan Pangan di Indonesia. Indonesian Journal of Statistics and Its Applications (eISSN:2599-0802) Vol 4 No 1 (2020), 136 - 155

Mbuli, C.S., Fonjong, L.N., \& Fletcher, A.J. (2021). Climate Change and Small Farmers' Vulnerability to Food Insecurity in Cameroon. Sustainability 2021, 13, 1523.

https://doi.org/10.3390/su13031523.

Nord, M. (2014). Introduction to item response theory applied to food security measurement: Basic concepts, parameters, and statistics (Vol. 2014). Rome (IT): FAO.

Olusayu, O., Adebayo, O., Kayode, S.K., Olagunju, K., Ayodeji, I., \& Ogundipe, A.A. (2019). Small-scale farming, Agricultural Productivity and Poverty Reduction in Nigeria: the Enabling Role of Agricultural Technology Adoption. Journal of Agriculture and Ecology International. July 2019. 
Rapsomanikis, G. (2015). The Economic Live of Small Holders Farmers: An Analysis based on household data from nine countries. FAO Rome.

Saint Ville, A., Po, J.Y., Sen, A., Bui, A., \& Quinonez, H. M. (2019). Food security and the Food Insecurity Experience Scale (FIES): ensuring progress by 2030. Food Sec. 11, 483-491. https://doi.org/10.1007/s12571-019-00936-9.

Smith, M.D., Kassa, W., \& Winters, P. (2017). Assessing food insecurity in Latin America and the Caribbean using FAO's Food Insecurity Experience Scale. Food Policy 71 (2017) 48-61.

Snyder, S., Sheehan, R. (1992). The Rasch Measurement Model: An Introduction. Journal of Early Intervention. 16(1):87-95. doi:10.1177/105381519201600108.

Wambogo, E. A., Ghattas, H., Leonard, K. L., Sahyoun, N. R. (2018). Validity of the Food Insecurity Experience Scale for Use in Sub-Saharan Africa and Characteristics of Food-Insecure Individuals. Oxford University Press. 